\title{
Analysis of Territorial Planning and Prospects for Further Development of Urban Districts and Settlements in Rostov Region
}

\author{
Natalia Ovchinnikova ${ }^{1, *}$ \\ ${ }^{1}$ Don State Technical University, pl. Gagarina, 1, Rostov-on-Don, 344010, Russia
}

\begin{abstract}
This article covers the problems of modern urban districts and settlements of the Rostov region with due regard to the organization of their territories. Prospects for the further development of the urban districts and settlements are defined based on the goals of the urban-planning activity. Short-term and mid-term trends of residential construction in the Rostov region are classified in terms of the improvement of town-planning documentation. It is concluded that the territorial planning organization is an integral part of sustainable territorial and urban development of any region.
\end{abstract}

\section{Introduction}

As a rule, a populated settlement is a point where economic, political and social activities are concentrated. Problems of modern cities can be considered as a specific demographic populated system integrated into the natural environment. Over the last years an economic component in the management of urban districts and settlements development has been playing center stage covering not only environmental issues but also an optimal ratio of the elements of artificial and natural environment required for creation of favorable living conditions for the population.

Besides, it is necessary to determine whether it is expedient to supply production with natural resources to the maximum extent. The pending problem is to determine the priority of the resources consumption, evaluate each territory in order to determine what kind of business activities would be the most suitable for it, and choose the one that would meet the characteristics of such area to the most extent.

From this perspective, the task of urban-planning activities involves purposeful management of citizens settlement systems as the society cannot develop, and the biosphere - be maintained without proper distribution of functions between their areas and rational specialized consumption of natural resources. Due maintenance of the planning spaces and rational profiling of the town-planning base of urban districts and settlements can reduce the damage to the natural environment [1-8].

\footnotetext{
Corresponding author: donong160875@yandex.ru
} 


\section{The role of territorial planning and urban-planning zoning in the development of urban districts and settlements.}

Social and economic development of a city is closely interrelated with the organization of its territories.

It can be achieved by territorial planning and zoning used to determine the locations of the housing, communal, social, engineering, transport, industrial, recreational and other infrastructure taking into account all the available possibilities and limitations.

Pursuant to the Town Planning Code of the Russian Federation, Articles 46.1-46.3, in order to develop built-up areas, liquidate emergency housing stock the following activities are to be carried out:

- Implementation of works necessary for the formation and allocation of land plots as part of the cooperation with the industry (functional) authorities of the municipal administration of the urban districts and settlements;

- Control and management within the scope of established functions of local government authorities;

- Performing functions related to the control over the placement of advertising and information elements on the territory of municipal districts and settlements, and their technical condition.

As part of the implementation of the priority tasks, it is also required to introduce some amendments to the Master Plan of the city, the Rules of land use and building, preparation of land planning documentation, formation of land plots for private housing construction, allotment of land plots under construction of socially important facilities, and development of built-up areas.

\section{Basic trends of the territory planning in the Rostov region.}

The architectural look of a municipal entity can be improved, and the integrated urban environment can be established through the urban design, the development of concepts and programs for the comprehensive artistic and promotional decoration of the city in order to prepare for the state and municipal festivals including the FIFA World Cup in 2018.

The main trends of the housing construction in the Rostov region for the short and medium term are established with due regard to the existing situation in the housing market, draft Territorial Planning Scheme of the Rostov region, planned location of productive forces, current and projected needs of citizens in housing and their purchasing power, the strategy of social and economic development of the Rostov region for the period up to 2020, related initiatives of the federal and regional gorvernmental authorities [9-11].

When determining the development perspectives of the urban districts and settlements in the Rostov region, the following factors are to be considered:

- Number of inhabitants taking into account the natural population increase, positive migration balance and commuting;

- Status of an urban district or settlement and its role in a system of service centers being established (on a local, district, town, region, and inter-district level);

- Historical factors (the existing objects of cultural heritage);

- The prospects for the development of the urban districts and settlements.

\section{Development and implementation of some measures aimed at stimulation of the supply and demand on the housing market.}


Depending on the population size over the forecast period, the urban districts and settlements of the Rostov region are classified into the following groups as per Table 1 below.

Table 1. The urban districts and settlements of the Rostov region

\begin{tabular}{|c|c|c|}
\hline \multirow[b]{2}{*}{ Groups } & \multicolumn{2}{|c|}{ Population, ' 000 people } \\
\hline & Towns and cities & $\begin{array}{c}\text { Rural } \\
\text { settlements }\end{array}$ \\
\hline The largest cities (Rostov-on-Don) & more than 1,000 & - \\
\hline \multirow{2}{*}{ Large cities (Taganrog) } & from 500 to 1,000 & from 5 to 10 \\
\hline & from 250 to 500 & from 3 to 5 \\
\hline $\begin{array}{c}\text { Cities (Volgodonsk, Novocherkassk, Bataysk, } \\
\text { Novoshakhtinsk, Shakhty) }\end{array}$ & from 100 to 250 & from 1 to 3 \\
\hline $\begin{array}{c}\text { Mid-sized towns (Asov, Donetsk, Gukovo, } \\
\text { Kamensk-Shakhtinsky, Salsk) }\end{array}$ & from 50 to 100 & from 0.2 to 1 \\
\hline \multirow{3}{*}{$\begin{array}{c}\text { Small towns* (Zverevo, Millerovo, Morozovsk, } \\
\text { Proletarsk, Semikarakorsk, Ust-Donetsk, } \\
\text { Tsimlyansk) }\end{array}$} & from 20 to 50 & $\begin{array}{c}\text { from } 0.05 \text { to } \\
0.2\end{array}$ \\
\hline & from 10 to 20 & up to 0.05 \\
\hline & up to 10 & - \\
\hline
\end{tabular}

Based on their functional use, the territories of the urban districts and settlements are divided into the following zones:

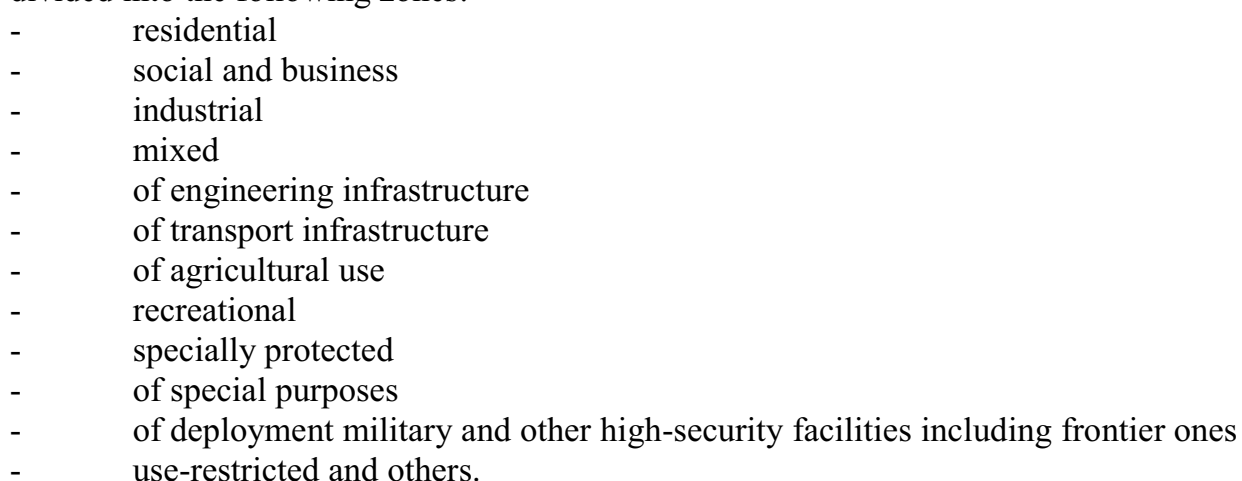

The construction in general contributes to the economic and social development of the Rostov region. Thus, there is need for the development and practical implementation of the measures aimed at stimulating supply and demand in the housing market that involves the solution of the following tactical tasks:

1. Increase in volumes of the housing construction, stimulation of low-rise buildings construction;

2. Provision of land plots under the housing construction;

3. Improvement in providing the population with social services.

The low-rise residential housing represents a reserve for boosting the construction. Low-rise settlements can be simultaneously built over the whole region developing various small and medium-sized businesses, involving local labor and local resources. The low-rise construction requires much less labor costs. Modern technologies allow building without the use of heavy equipment, reducing the time and cost of construction, quickly solving the problem of affordable housing. For the purpose of providing housing construction with the land plots, the complex development of the territories to be built-up including their provision with engineering infrastructure, involvement of land plots into the business 
circulation including the federal lands is performed. To accommodate a residential area the most favorable in terms of hygiene, engineering and geology land plots that require a minimum of land use engineering, planning activities and activities for preserving natural state of the environment are chosen. Residential areas should be located within the boundaries of human settlements. Architectural and planning concepts of the residential zone development are to be reconciled with simultaneously developed engineering solutions. Any territories under garden and summer houses located within the boundaries of human settlements are also considered as residential areas. The development of social, transport and engineering infrastructures in respect of these areas is to be envisaged in order to provide the possibility of the future residence. For preliminary determination of overall size of residential areas it is allowed to accept consolidated indices on a basis of 1,000 persons: in the cities - in case of average storey's number of residential buildings up to 3 floors - 10 hectares for the buildings without any land plots, and 20 hectares - for the buildings with land plots; from 4 to 8 floors -8 hectares; 9 floors and above -7 hectares; in rural areas with predominantly homestead-type houses of up to 40 hectares. For preliminary determination of the required area under the low-rise residential development in a rural settlement it is allowed to take the following indicators per a house (apartment), hectare (hectare), when building:

- Individual residential houses, homestead-type residential houses (flats) with adjoining land plots as per Table 2 below:

Table 2. Area of the adjoining land plot and residential space

\begin{tabular}{|c|c|}
\hline Area of the adjoining land plot, $\mathrm{m} 2$ & Residential space, ha \\
\hline 2,000 & $0.25-0.27$ \\
\hline 1,500 & $0.21-0.23$ \\
\hline 1,200 & $0.17-0.20$ \\
\hline 1,000 & $0.15-0.17$ \\
\hline 800 & $0.13-0.15$ \\
\hline 600 & $0.11-0.13$ \\
\hline 400 & $0.08-0.11$ \\
\hline
\end{tabular}

- Buildings of sectional type and blocked houses without land plots - as per Table 3 below:

Table 3. Number of storeys and residential space

\begin{tabular}{|c|c|}
\hline Number of storeys & Residential space, ha \\
\hline 2 & 0.04 \\
\hline 3 & 0.03 \\
\hline 4 & 0.02 \\
\hline
\end{tabular}

Approximate structure of the housing stock differentiated by the level of comfort - as per Table No 4 below:

Table 4. The structure of the housing stock differentiated by the level of comfort

\begin{tabular}{|l|l|l|}
\hline $\begin{array}{l}\text { Type of residential house } \\
\text { and apartment based on } \\
\text { level of comfort }\end{array}$ & $\begin{array}{l}\text { Norm of dwelling space in residential } \\
\text { house (apartment) per person, } \mathrm{m}^{2}\end{array}$ & $\begin{array}{l}\text { Formula for calculation } \\
\text { occupancy of residential } \\
\text { house and apartment }\end{array}$ \\
\hline $\begin{array}{l}\text { VIP } \\
\text { (business class) }\end{array}$ & $40-45$ & $\begin{array}{l}\mathrm{k}=\mathrm{n}+1 \\
\mathrm{k}=\mathrm{n}+2\end{array}$ \\
\hline $\begin{array}{l}\text { Mass housing } \\
\text { (economy class) }\end{array}$ & $\begin{array}{l}\mathrm{k}=\mathrm{n} \\
\mathrm{k}=\mathrm{n}+1\end{array}$ \\
\hline $\begin{array}{l}\text { Social } \\
\text { (municipal housing) for } \\
\text { calculations in projects }\end{array}$ & $\begin{array}{l}18 \\
\text { projected in compliance with changes } \\
\text { in legislation }\end{array}$ & $\begin{array}{l}\mathrm{k}=\mathrm{n}-1 \\
\mathrm{k}=\mathrm{n}\end{array}$ \\
\hline Specialized & According to special norms & $k=n-2 k=n-1$ \\
\hline
\end{tabular}


In order to improve the provision of the population with social services, it is necessary to exercise the powers in terms of construction, reconstruction including the development of design and estimate documentation, social facilities. While implementing this goal, it is necessary to provide the population with the modern social facilities through the construction of new and reconstruction of existing educational facilities including preschool institutions, health care, sports, environmental and socio-cultural facilities, development of design and estimate documentation. For these purposes some separate, built-in or built-on facilities intended for social and municipal needs, trade, health care, preschool, primary and secondary (complete) general education facilities, religious buildings, parking, other objects that are related to the people comfortable habitation and make no negative impact on the environment are placed. The recommended specific indicators of specified elements of a micro-district (block) are listed in Table 5 below:

Table 5. The recommended specific indicators of specified elements of a micro-district

\begin{tabular}{|c|l|c|}
\hline $\begin{array}{c}\text { Item } \\
\text { Nos }\end{array}$ & \multicolumn{1}{|c|}{ Elements of micro-district territory } & Specific area, sq.m per person, not less \\
\hline 1. & $\begin{array}{l}\text { Total territory } \\
\text { including: } \\
\text { Schools area }\end{array}$ & 15.5 \\
\hline 2. & Preschools area & 4.3 \\
\hline 3. & Planting area & 1.5 \\
\hline 4. & Service objects area & 6.0 \\
\hline 5. & Closed parking area & 1.1 \\
\hline
\end{tabular}

Grounds of yard improvement (composition, number and size) located in micro-districts (blocks) of residential areas are to be foreseen in the design assignment with due consideration of the demographic composition of the population and specified elements. However, the total area of the territory under children's playgrounds, sites for rest and physical training of adult population must comprise at least $10 \%$ of the total area of a residential block (micro-district). Specific indicators of the yards improvement are listed in Table 6 below:

Table 6. Specific indicators of the yards improvement

\begin{tabular}{|l|c|}
\hline Sites & $\begin{array}{l}\text { Specific dimensions of the sites, sq.m per } \\
\text { person }\end{array}$ \\
\hline $\begin{array}{l}\text { Playgrounds for preschool and junior school } \\
\text { children }\end{array}$ & 0.7 \\
\hline Grounds for recreation of adults & 0.1 \\
\hline Sports grounds & 2.0 \\
\hline Public utility sites and dog-walking grounds & 0.3 \\
\hline Parking places & 0.8 \\
\hline $\begin{array}{l}\text { Notes. It is allowed to reduce specific dimensions (but no more than by 50\%) of the following: } \\
\text { public utility sites when developing residential buildings of 9-storeys and higher; }\end{array}$ \\
$\begin{array}{l}\text { sports grounds when establishing a fitness center of the block (micro-district) for } \\
\text { schoolchildren and adults. }\end{array}$ \\
\hline \multicolumn{2}{|c}{} \\
\hline
\end{tabular}




\section{Conclusion}

For the last decade the urban planning of Russia has been experiencing a complex and difficult period due to various changes in the geopolitical, social and economic situation in the country. The theory and practice of the urban planning appeared to be unprepared for the new terms of development. Many provisions of the urban-planning policy which has been developed under the conditions of the previous period became useless, and spontaneous market forces became evident in disarrangement of the planning and development of residential areas.

The special feature of the territorial and urban development of the Rostov region is that a huge impact on its formation has been exerted by its geographical location, mentality of the people living there, political and economic interests of the state.

Under present conditions, the territorial and urban-planning activities in the Rostov region are carried out in three main directions: the development of the construction industry, sustainable territorial and urban-planning development, and the liquidation of worn-out and emergency buildings.

Thus, with the constantly improving legislation in the area of urban development, the role of the urban development as a whole has increased greatly including territorial-planning organization that constitutes an integral part of the sustainable territorial and urbanplanning development of urban districts and settlements of the Rostov region.

\section{References}

1. V.V. Okrepilov, V.L. Makarov, A.R. Bakhtizin, S.N. Kuzmina, Economy of Region, 2, 301-313 (2015) DOI: 10.17059/2015-2-24

2. G. Radovic,V. Murgul, N. Vatin, Applied Mechanics and Materials, 641-642, 634638 (2014)

3. N.G. Ovchinnikova, Construction and Architecture - 2015, Materials of the International Science and Practice Conference (2015)

4. N.G. Ovchinnikova, E.S. Shumkova, Economy and Ecology of Territorial Entities, 2, 2016

5. N.G. Ovchinnikova, A.M. Ivanova, O,V, Lutoshechkina, Economy and Ecology of Territorial Entities, 1, 2014

6. N.G. Ovchinnikova, O.V. Bruzhukova, Bulletin of the Moscow State University of culture and arts, 4(60) (2014)

7. A.P. Pustovgar, L.A. Shilova, A.O. Adamtsevich, L.A. Shilov, International Journal of Applied Engineering Research, 10 (20) 40988 - 40990 (2015)

8. B. Kovačič, R. Kamnik, A. Pustovgar, N. Vatin, Procedia Engineering, 165, 918925. DOI: 10.1016/j.proeng.2016.11.801

9. Town Planning Code of the Russian Federation of 29.12.2004 190-FZ

10. Land Code of the Russian Federation of 25.10.2001 N 136-FZ

11. Federal Law of December 29, No.191-FZ (2004) 